DISCUSSION NOTE

\title{
Response to Kosterec
}

\author{
Daniela Glavaničová*
}

Miloš Kosterec raised four objections against the analysis of fictional names proposed in my paper on fictional names (see [Kosterec 2018] and [Glavaničová 2017], respectively). The paper was devoted to two analyses of fictional names within Transparent Intensional Logic (TIL). The former was the analysis actually proposed by the founder of TIL Pavel Tichý in his "green bible," The Foundations of Frege's Logic. Tichý analysed fictional names in terms of free variables. This analysis was briefly explained and assessed in the paper. The latter analysis was my own, in its very first version. This second analysis made use of Tichý's notion of individual roles (offices, things-to-be). I reminded the reader of the affinity of this analysis to the account of fictional names known as role realism. ${ }^{1}$

Kosterec in his discussion of my paper rightly observes that there is some tension between roles as understood in TIL and roles as understood in my paper. While the former is a functional, intensional object, the latter is much closer to an individual concept, which is a hyperintensional object, or to the

1 The most prominent advocates of this position are Wolterstorff (1980), Currie (1990), Lamarque and Olsen (1994) and Lamarque (2009; 2010). Arguably, a version of role realism was also formulated in (Tiedke 2011).

* Institute of Philosophy of the Slovak Academy of Sciences

Institute of Philosophy, Slovak Academy of Sciences, Klemensova 19, 81364 Bratislava, Slovak Republic

$凶$ daniela.glavanicova@gmail.com

(C) The Author. Journal compilation (C) The Editorial Board, Organon F.

This article is distributed under the terms of the Creative Commons Attribution-NonCommercial 4.0 International Public License (CC BY-NC 4.0). 
hyperintensional analysis of (im)possible individuals suggested by Cmorej (2015a, 2015b). ${ }^{2}$

This paper explains the main objection formulated by Kosterec and shows some preliminary evidence in my defence (Section 1). Subsequently, a clarification is made, providing necessary means for responding to Kosterec's worry (Section 2). Subsequently, my analysis in its current state is briefly explained (Section 3). Finally, the paper responds to the main objection formulated by Kosterec (Section 4). As further worries and challenges largely depend on the main objection, I will postpone the response to these other objections until the main objection is thoroughly discussed.

\section{The main objection}

The main objection formulated by Kosterec was as follows: In TIL, there is only one necessarily empty individual role. As the fictional names are analysed in terms of necessarily empty roles, the very same object is assigned to all fictional names.

I acknowledge that this is true if the notion of roles is precisely the same as the one used in TIL. Yet the reader was reminded several times that this is clearly not so (though, granted, the provided analysis was just a preliminary one). To begin with, I differentiated between hyperintensional, intensional, and extensional occurrences of fictional names (Glavaničová 2017, 397). Moreover, I stated clearly that the proposal requires such a notion of roles that allows for different (constructions of) necessarily empty roles (Glavaničová 2017, 398 and 399).

Above I have said that the employed notion is "much closer" to individual concepts, but haven't said it was "identical." This has been no accident! The upshot is that there are at least two ways how to individuate roles to avoid the problem of ending up with just one necessarily empty role. One of them is employing the notion of hyperoffice, the other is to individuate

2 Some challenges were raised in (Kotátko 2017). A brief suggestion to extend Cmorej's approach to fictional entities can be found in (Zouhar 2017, 134, footnote $3)$. 
roles also in terms of their requisites. However, it needs to be said that the former option seems to be much more plausible if we find ourselves within the framework of TIL, the latter seems to be more plausible if the notion of roles as used in role realism is employed. For roles of role realism can be understood (with possible further corrections, amendments and clarifications) as sets of requisites.

\section{The clarification: roles}

To keep the matters precise, let me make some clarifications. In the paper under the discussion, I oscillated between three readings of the term role:

(i) role understood as an intensional object within the TIL hierarchy: a function from possible worlds (and times) to individuals - this is the notion of roles (or offices) as used in TIL community; and this is the notion of roles Kosterec rightly worries I have in mind when speaking about fictional characters;

(ii) role as construed by role realism, which amounts to a requisite set in TIL - roles in this sense can be understood as sets of essential properties of fictional characters; note, however, that a precise specification of which properties fall into this heading and which do not is not an easy task even in particular casesand probably is not even a task for a semanticist, but a task for a literary critic; a general procedure for generating these properties is not easier than a procedure for generating truth(s) in fiction; and

(iii) individual concept, a hyperintension (TIL construction) constructing an intensional role.

From now on I will use the term individual role for (i), the term role for (ii), and the term individual concept for (iii). 


\section{My analysis: the present state}

While the paper under discussion contained only some basic ideas of my future account, my chapter (Glavaničová 2018) presents the analysis more clearly, with the focus to the class of standard problems in the area and ways how to account for them. Yet both (Glavaničová 2017) and (Glavaničová 2018) were rather informal, and both oscillated between roles in three different senses explained above.

The proposal in its current, more elaborated state, can be summed up as follows: There are fictional names de dicto and fictional names de re. De dicto analysis of fictional names is a form of hyperintensional role realism. The sense of a fictional name is an individual concept (a hyperintension) associated with a set of requisites. The requisite set is basically the same thing as a role of role realism (for instance, being a detective is a requisite of Sherlock Holmes; being an unhappily married woman is a requisite of Thérèse Raquin). While the sense is an abstract entity, the reference, if any, is a concrete person. However, while the sense exists, the reference does not. Moreover, there is (necessarily!) no reference, no full-blooded Sherlock Holmes. ${ }^{3}$

One can formulate two semi-formal analyses within the above setting. The first one is a TIL-friendly analysis. This analysis distinguishes hyperintensional, intensional and extensional occurrences of fictional names.

The second analysis is a simplification of the first analysis that partially departs from standard TIL analyses. The second analysis distinguishes de dicto (hyperintensional) and de re (extensional) occurrences only. One level disappears, which means that the work done on this level had to be moved "upwards" (hyperintensionality) or "downwards" (extensionality). My suggestion is to move upwards. The work previously done by intensions is thus done by hyperintensions.

\footnotetext{
3 A similar suggestion (fictional characters being impossible) was made in (Vacek 2018). See also (Vacek 2017) for the framework employed.
} 


\section{The response}

Now on either of the two analyses explained in the previous section, the Kosterec's worry does not arise. For the individual concept pertaining to the name Holmes is different from the individual concept pertaining to Watson. I am an individual numerically different from Miloš Kosterec. Similarly, Holmes-concept is numerically different from Watson-concept. Now this distinctness might have different reasons. Probably the best explanation is that the Holmes-concept is joined with a different set of requisites than the Watson-concept. In this way, a crucial usage of roles is made.

Yet at least one worry remains. The notion of requisites was formulated only for things that are at least possible. However, I can reveal that the first attempts to overcome this limitation have been made within the TIL community. Yet still a lot of work remains to be done till we arrive at a hyperintensional notion of requisites which would be sufficient for generating requisites of fictional characters.

\section{Funding}

This paper was supported by VEGA grant no. 2/0117/19 Logic, Epistemology, and Metaphysics of Fiction.

\section{References}

Cmorej, Pavel. 2015a. "Možné indivíduá a posibílie I" ["Possible Individuals and Possibilia I"]. Filozofia 70 (8): 585-600.

Cmorej, Pavel. 2015b. "Možné indivíduá a posibílie II" ["Possible Individuals and Possibilia II"]. Filozofia 70 (10): 800-46.

Currie, Gregory. 1990. The Nature of Fiction. Cambridge: Cambridge University Press. https://doi.org/10.1017/CBO9780511897498

Glavaničová, Daniela. 2017. "Tichý and Fictional Names." Organon F 24 (3): 384404.

Glavaničová, Daniela. 2018. "Fictional Names and Semantics: Towards a Hybrid View." In Objects of Inquiry in Philosophy of Language and Literature. Studies in Philosophy of Language and Linguistics, 59-73. Berlin: Peter Lang.

Kosterec, Miloš. 2018. "Some Problems of Glavaničová's Approach to Fictional Names." Organon F 25 (1): 120-25. 
Kotátko, Petr. 2017. "Nemožný mravenec a konfúzní fikce" ["An Impossible Ant and Confused Fiction"]. Organon F 24 (Supplementary Issue): 50-63.

Lamarque, Peter, and Stein Haugom Olsen. 1994. Truth, Fiction, and Literature: A Philosophical Perspective. Oxford: Oxford University Press. https://doi.org/10.1093/acprof:oso/9780198236818.001.0001

Lamarque, Peter. 2009. The Philosophy of Literature. Oxford: Blackwell.

Lamarque, Peter. 2010. Work and Object: Explorations in the Metaphysics of Art. Oxford: Oxford University Press. https://doi.org/10.1093/acprof:oso/9780199577460.001.0001

Tiedke, Heide. 2011. "Proper Names and Their Fictional Uses." Australasian Journal of Philosophy 89 (4): 707-26. https://doi.org/10.1080/00048402.2010.514930

Tichý, Pavel. 1988. The Foundations of Frege's Logic. Berlin and New York: de Gruyter.

Vacek, Martin. 2017. "Extended Modal Dimensionalism." Acta Analytica 32 (1): 13-28. https://doi.org/10.1007/s12136-016-0297-9

Vacek, Martin. 2018. "Fiction: Impossible!" Axiomathes 28 (2): 247-52. https://doi.org/10.1007/s10516-017-9353-3

Wolterstorff, Nicholas. 1980. Works and Worlds of Art. Oxford: Clarendon Press. Zouhar, Marián. 2017. "Fiktívne objekty a ich vlastnosti: niekolko problémov" ["Fictional Objects and Their Properties: Several Problems"]. Organon F 24 (Supplementary Issue): 132-52. 